\title{
\#Metoo/\#Aidtoo and Creating an Intersectional Feminist NPO/NGO Sector
}

\author{
${ }^{1}$ School of Public Administration, University of Nebraska at Omaha, Omaha, Nebraska, USA, E-mail: \\ egillespie@unomaha.edu, aeikenberry@unomaha.edu.https://orcid.org/0000-0002-6493-182X. \\ ${ }^{2}$ Department of Political Science and Public Affairs, Seton Hall University, South Orange, N], USA, E-mail: \\ Roseanne.Mirabella@shu.edu
}

\begin{abstract}
:
The purpose of this essay is to explore the implications of \#metoo and \#aidtoo for understanding nonprofit/nongovernmental organization (NPO/NGO) theory and practice. We provide an overview of how women have experienced sexual violence in the context of NPOs/NGOs and draw on an intersectional feminist theory lens to highlight the context that enables violence to persist, and which requires more than implementing bureaucratic accountability reforms. We end by discussing potential avenues for creating change to end such violence.
\end{abstract}

Keywords: \#metoo, \#aidtoo, feminist theory, intersectionality

DOI: $10.1515 / \mathrm{npf}-2019-0019$

\section{Introduction}

The purpose of this essay is to explore the implications of \#metoo and \#aidtoo for understanding nonprofit/nongovernmental organization (NPO/NGO) theory and practice. ${ }^{1}$ The \#metoo movement started in the U.S. more than a decade ago as a grassroots effort to show support for survivors of sexual violence, principally for young women of color from low wealth communities, but has recently gained prominence when the \#metoo hashtag went viral (Me Too Movement 2018). After the news broke of Oxfam workers paying for sex in Haiti, as well as additional examples of sexual violence coming to light at other NGOs (Bacchi 2018), women in the global aid sector promoted their own version of \#metoo, using the hashtag \#aidtoo, to bring attention to sexual violence in the humanitarian aid sector. ${ }^{2}$ NPO/NGOs - especially humanitarian aid organizations - are expected to protect the most vulnerable in society, yet some (perhaps many) clearly fail as we have seen with \#metoo/\#aidtoo stories.

The response to such situations in the past has been to call for stronger organizational accountability and bureaucratic reforms (Berdahl and Raver 2011; Garrie 2011) and in more recent cases, improving codes of ethics (Carolei 2019). Organizations such as Oxfam are tightening up their "safeguarding" procedures (Carolei 2019; Oxfam 2018). However, feminist theorists have argued sexual violence persists not due merely to lax rules, ethical codes, or lack of reporting, but because these organizations exist within a larger context that oppresses women, people of color, and other marginalized groups (Crenshaw 1990; Hunnicutt 2009; Jasinski 2001; Kalra and Bhugra 2013). Approaching sexual violence merely through a set of organizational reforms or tightening up ethical codes is inadequate. \#metoo/\#aidtoo show the need for broader systemic change in our thinking, culture, and practice. Research on violence against women suggests the broader context and social structures must be changed to address violence against women (Sokoloff 2004; Yodanis 2004). A feminist theory lens highlights the context that enables violence to persist and potential avenues for creating change to end such violence.

The rest of the paper is organized as follows: First, we provide an overview of how women have suffered violence in the context of NPOs/NGOs, particularly humanitarian aid organizations, and why this seems to persist. Next, we discuss an intersectional feminist approach for addressing these conditions and provide suggestions for what this might look like in theory and practice. We end with a brief summary and conclusion.

Angela M. Eikenberry is the corresponding author

(c) BY (c) 2019 Gillespie et al., published by De Gruyter

This work is licensed under the Creative Commons Attribution 4.o Public License. 


\section{Sexual Violence Against Women in the Context of NPOs/NCOs}

Sexual violence in the NPO/NGO sector, especially in the humanitarian aid industry, has been well documented (Ather 2013; Danyi 2019; House of Commons 2018; Kunwar et al. 2015; Shapiro 2018). The exact number of individuals in the sector who have been sexually violated is difficult to quantify, as many agencies are unable or unwilling to provide figures. A recent Harris poll conducted in the U.S. and Canada found that approximately one in two fundraising professionals have had some sort of personal exposure to sexual harassment in the workplace, either witnessing, hearing about, or experiencing sexual harassment themselves (Harris Insights \& Analytics 2018). In addition, a survey of humanitarian aid workers conducted by Humanitarian Women's Network (2016) found 48 percent of female humanitarian workers reported being touched in an unwanted way. Further, 55 percent reported being subjected to "persistent romantic or sexual advances from a male colleague" (2). On Twitter, the hashtag \#aidtoo details countless stories of humanitarian aid workers and beneficiaries who have been abused or assaulted by aid workers in the field. Thus, although Oxfam and other recent scandals have brought the issue to the fore, violence against women in the NPO/NGO sector - both workers and beneficiaries - has been going on for a long time and is perhaps much more pervasive than many realize.

Such sexual violence continues despite the reporting, monitoring, and public attention to the issue. For example, Oxfam, an organization highlighted as having the best practice for addressing sexual harassment and abuse (Mazurana and Mazurana 2017, 52), was still unable to prevent continued violence against women. Why does sexual violence persist despite these efforts? Drawing on feminist perspectives, we suggest several intersecting social and cultural reasons to consider, including: institutional power disparities, a misogynist culture, gender mainstreaming, a focus on the individual victim and perpetrator, and the capitalist system. We discuss each of these in turn.

\section{Institutional Power Disparities}

Institutional power disparities engrained in bureaucratic organizations enable one person in an institution (a supervisor) to control the fate of another (a subordinate) based on their roles in the institutions (Ferguson 1984; Leong 2019). Women are underrepresented in positions of power within bureaucratic organizations (Tremblay 1999, 75), including in nonprofit leadership positions (Hallock 2002; Nozawa 2010; Sampson and Moore 2008; Teasdale et al. 2011) even though the majority of employees in the nonprofit sector are women (Lanfranchi and Narcy 2015; Renock 2017). Such uneven power dynamics create structural inequalities for women employees and beneficiaries alike, putting them at greater risk of sexual violence (Sandoval 2018). Tremblay (1999) also maintains that the "universalizing and homogenizing concepts of administration" are centered on "nonbias and discrimination against women (see also Stivers 1993).

\section{A Misogynist Culture}

Even though there are an abundance of policies related to sexual violence, research suggests these cannot adequately protect women in misogynist cultures that are strongly prejudiced against women (Becker 1999; Kalra and Bhugra 2013). Carline and Easteal (2014) argue the supposed neutral and objective outlook used in legal approaches to ending violence against women actually overlooks gender, which only serves to perpetuate a culture and system that fails to account for women's lived experiences. Research suggests the success of legal and bureaucratic approaches rests on believing what a woman says is true; misogyny works against this (Gilbert 2002; Lakeman 2000). As we see repeatedly in sexual abuse cases, there must be a preponderance of evidence for a woman's account to be believed, because the value of the man outweighs the "sexualized worthlessness" of the woman in a misogynist cultural context (MacKinnon 2018). The result is a system of unequal power dynamics "in which the more power a man has, the more sexual access he can get away with" (MacKinnon 2018). Women are thus taught any "opposition to power will produce retaliation" (MacKinnon 2018). A fear of retaliation might contribute to underreporting of sexual violence. A 2018 study on gender inequalities in the workplace found less than 3 percent of sexually harassed and assaulted women in the U.S. confront the perpetrator and just over 10 percent of women file official complaints or reports to an authority figure; yet, $65 \%$ of U.S. adults think sexual harassment of women in the workplace is a serious problem and $27 \%$ of women report being "very concerned" about whether the \#metoo movement will cause women to be "denied professional opportunities because men are reluctant to work with them" (Deggans 2018, 47). 


\section{Gender Mainstreaming}

Despite this, the aid industry has embraced a "neutral" orientation of gender that ignores the prevailing structures of patriarchy. According to Lerner (1986), patriarchy has been the dominant social structure for all of human history. It oppresses women by creating and sustaining systems and structures that subordinate women to men resulting in social, political, and economic barriers to gender equality and sustains the acceptability of violence against women (Namy et al. 2017; Tong 2013). Feminists are skeptical of this neutral approach, which they refer to as the "gender mainstreaming" of women's rights (Eveline and Bacchi 2006; Winter 2012). Research on gender mainstreaming, including the UN Women's (2014) report on gender mainstreaming in development programs, indicates that attempts at gender mainstreaming in the aid community have primarily focused on technical aspects of gender and inclusion, such as focusing on number of women served. Here, gender is largely reduced to understanding abstracted differences as reported to funders by NGOs in their numeric targets, with little if any attention paid to underlying power structures and relationships in the everyday lives of women (Wallace, Bornstein, and Chapman 2007). Gender mainstreaming ignores that sexual violence is often a "direct result of economic inequality, colonization, and other forms of state violence, and of patriarchal and heterosexual norms" (Kivel 2007, 143).

\section{A Focus on the Individual}

Another factor in continued violence against women is the privatization of the offense (Miller 2004). Undergirded by a neoliberal and western emphasis on individual responsibility, the focus on violence against women has become "more and more a behavioral, criminal, and medical phenomenon, rather than a social justice issue"(Durazo 2007, 117). With the proliferation of international aid agencies came the application of Western understandings of rape and violence in the international arena, including referring to sexual violence within a human rights discourse as compatible with the individualism of market discourse (Alcoff 2009; Miller 2004). This frame of prosecuting and punishing those accused of sexual violence became the norm (St. Germain and Dewey 2012) and has now become "best practice" in the aid industry, referred to as the "consensus model" (Herzog 2010, 6). When violence against women is seen as a human rights violation, it establishes a tension between rights and the broader cultural context. As Merry (2011) notes, interpersonal gender violence cannot "be tackled without simultaneous efforts to deal with global conflict, economic inequality, and a lack of social justice" (186).

\section{The Capitalist System}

Finally, the capitalist context in which NPOs/NGOs exist functions as a tool for violence as it gives power to a very few at the expense of the majority (Allen 2016). Together, patriarchy and capitalism prevent the most marginalized, especially low-income and/or women of color, from accessing power and resources (Harnois 2012). Although Marx rightly recognized the alienation of laborers from the fruits of their production through capitalism, he failed to take into account the gendered nature of work with an entire class of workers - women - systematically alienated from the fruits of their labor as a result of their labor being deemed "wage-less" (Federici 2018). As Federici (2018) notes: “One consequence of Marx's under-theorization of domestic work is that his account of capitalist exploitation and his conception of communism ignore the largest activity on this planet and a major ground of divisions within the working class" (471). Scholars, such as MacKinnon (1989), have argued that Marx privileged paid labor over unpaid labor and technological production over natural production rendering women's work far less valuable than that of men's work and set up a power imbalance between technical production and natural production, wage labor and reproductive labor. Valuing the work of men over that of women established a power imbalance between men and women both in the marketplace and in the family. Weldon (2019) opines that within this context, the removal of a few powerful men through the \#metoo movement will do little to advance equality for women or remove this gender imbalance. This will only occur through changes in larger "social norms and practices" (233).

\section{Intersectional Feminist Praxis \& Ending Sexual Violence in NPOs/NGOs}

Broadly, feminist scholars describe feminism as seeking to identify, critique, and challenge systems of injustice, oppression, and abuse supported by a patriarchal system (Becker 1999; Tong 2013). We have argued above that working within existing legal and bureaucratic structures is inadequate for challenging the conditions that 
enable sexual violence to persist in the context of NPOs/NGOs. Praxis ${ }^{3}$ must address the male dominance of power positions, a misogynist culture, "neutral" approaches to gender, a focus on the individual, and the capitalist, patriarchal system.

Radical feminists contend the patriarchy cannot be reformed; rather, it must be "ripped out root and branch" (Tong 2013, vii). As such, a radical feminist approach to end violence against women would demand an end to misogynist cultures and systems. A socialist/Marxist approach would focus on challenging the capitalist system that privileges patriarchy and eliminating both systems. A liberal feminist approach emphasizes women's full autonomy and freedom through welfare reforms and changes within existing legal and bureaucratic structures to change this system (Tong 2013). Carastathis (2014) suggests, an intersectional approach to ending violence and fashioning a feminist NPO/NGO sector might incorporate elements of all three perspectives. Originally coined by Crenshaw (1989), intersectionality incorporates "recognition of the multiplicity" of oppressive systems and challenges the role oppressive systems play in the "production and reproduction of social inequalities" (Bilge 2010, 58). For example, black feminists have pushed back against the white feminist narrative of linking abuse solely to the patriarchy, arguing that inequality can only be erased through "attention to the complex, interlocking structures of oppression" (Hall 2015, 395) that are characteristic of racist, imperialist, and capitalist systems (Collins 2002). A feminist theory of nonprofit organizations "ought to be directed at the elimination of the conditions under which all forms of marginalization are sustained" (Nickel and Eikenberry 2006, 363-64).

Feminism is made up of diverse ideas and practices (Tong 2013; Schwabenland et al. 2016) and, as a whole, tends to not ascribe to universalisms (Anderson 2019). In the context of a multifaceted understanding of feminism, a feminist NPO/NGO sector would be heterogeneous in its theories and practices, or praxis (McAfee 2018). Feminist theories on bureaucratic organizations, power and gender, as an example, differ among scholars. For example, Ferguson believes women must challenge bureaucratic domination through the development of alternative organizations based on the diverse experiences of women. Conversely, Stivers supports seeking out places within current structures where creating change is possible (Tremblay 1999). Liberal feminist approaches might adopt Stivers' view and look for opportunities within current structures to create change, whereas radical feminist approaches may align more with Ferguson and the establishment of new organizational types and practices to address the inadequacies of a male-dominated culture. NPOs/NGOs worldwide already address women's empowerment and emancipation through a spectrum of approaches from individual empowerment to emancipation on a political level (Phillips 2016). NPOs/NGOs advocate formally through the state and "informally through public voice, protest and social media" (Phillips 2016, 23). They have succeeded in getting women's issues onto political agendas while also providing services to women in need (Cho, Crenshaw, and McCall 2013). An intersectional feminist NPO/NGO sector might embrace the use of different approaches towards a shared purpose of ending sexual violence against women.

We outline here several tentative suggestions about what "intersectional feminist NGOs/NPOs" might look like in practice. Specifically, they would seek to: address institutional power disparities by creating more feminist and democratic organizations; challenge misogynist culture by raising up the powerful voices of women; acknowledge and treat organizations as gendered and value-laden; locate the individual in context; and work toward a care-centered economic system.

\section{Create Feminist and Democratic Organizations}

Feminist theories place an emphasis on the fundamental relational aspects of the world and the self, one that is non-oppositional, nonhierarchical, and non-dualistic (Nickel and Eikenberry 2006). From this, feminist organization should be "based on ... eliminating false dichotomies or artificial separations, empowering women, democratizing organizational structures, valuing process, and linking the personal and the political" (Chernesky 1995, 73). It should embody notions of equality, caring, and nurturance over hierarchy, inequality, and impersonality (Ferguson 1984) and can be exemplified in a relational leadership approach that assumes the "intrinsic value of all persons" (Beck cited in Burnier 2003). An early example of such a conception of feminist democratic organization during the Progressive Era was practiced by Jane Addams at Hull House, where "Addams created an organizational culture and structure that encouraged individual initiative and self-governance" (Knight 1991, 125).

\section{Raise Up the Powerful Voices of Women}

Changing misogynist culture requires in part raising up the powerful voices of women. In particular, bringing an end to violence against women demands that their voices be heard and their experiences validated and used 
to inform decisions and practices. The scene envisioned by Burgess (2018) and other feminists theorizes gender towards a new understanding of power that "makes possible the conditions for a kind of political action that might value women [and others] differently, altering the very norms of recognizability that sanction women's speech and renders it both intelligible and believable" (Burgess 2018, 352). A feminist perspective of structural dominance contends that understanding the lived experiences of women is an important step towards changing the power structures and relationships that subject women to continued violence (Einspahr 2010). Specifically, Stivers (2000) argues that greater inclusion of women in positions of leadership/power can prompt an alternative to the male-dominated model. An example of this in practice is the French feminist group, La Barbe, which brings attention to lack of women in leadership positions. One way they do this is by physically disrupting board meetings where members are all men to bring attention to the underrepresentation of women on boards (Hildwein 2016).

\section{Treat Organizations as Cendered and Value-Laden}

As feminist scholars suggest, NPOs/NGOs must also acknowledge and treat organizations as gendered and value-laden (O'Neil and Hopkins 2015; Williams, Muller, and Kilanski 2012). Specifically, in the aid sector, ChangingAid (2018), a group of feminist women working in the sector, recommends that humanitarian agencies should, among other things, acknowledge that international development and humanitarian sectors are patriarchal and therefore systemically perpetrate and excuse violence against women and girls. They call for organizations to commit to changing norms and practices to empower women - particularly women who experience multiple forms of discrimination and oppression (including oppression based on race, ethnicity, gender identity, sexual orientation, class, etc.) - to change and challenge gender inequality, power differentiation based on other axis of oppression, and to promote safety for all. As Stivers (2000) and Sandberg and Elliott (2019) suggest, a feminist NPO/NGO sector would be motivated by care for the oppressed and driven by a culture of active engagement. Broader goals of the sector, such as justice and equality, they argue should be just as significant, or more so, than procedural efficiency. According to Crenshaw (1989), ending violence is grounded in knowledge about the structures that promote gender, racial, and class-based inequalities. Thus, the evolution of a feminist NPO/NGO can also be built upon research and the act of educating others about oppressive and violent gendered structures, so as to be able to develop new ideas, systems, and cultural norms.

\section{Locate the Individual in Context}

A feminist NPO/NGO would also locate the individual in context; seeing the personal as political. This aligns with Oxfam America's report on feminist leadership for women's rights, which draws on the work of feminist scholars (Wakefield 2017). When the personal becomes political, it is no longer "natural" for women, or any other group exploited outside the official realm of value, to be subjugated (Nickel and Eikenberry 2006). Ozkazanc-Pan (2019) asserts that both the "individual and collective dimensions of agency are worth considering simultaneously ... to recognize the possibilities for gender system change" (2). Hooks (1984) encourages a feminist movement against all types of violence through radical consciousness-raising to eliminate male domination. Consciousness-raising is an individual and group process of seeking and increasing access to knowledge and power. The process involves direct engagement with patriarchal systems and institutions supported by "collective dialogue and social action" (Summerson Carr 2003, 18-19). Consciousness-raising advances one's understanding of how "the ideology that legitimizes male domination" perpetuates oppression (Batliwala 1994, 132), which is pivotal to eliciting social action. Authors in the 2016 book, Women's Emancipation and Civil Society Organisations (Schwabenland et al. 2016) suggest that individual emancipation can be advanced through shared solidarity, which in turn challenges structures of patriarchal ideology.

\section{Work Toward a Care-Centered Economic System}

Finally, intersectional feminist NGOs/NPOs might work toward a care-centered economic system that "values care, makes care work visible, and places care values and practices at the center of [nonprofit] scholarship and practice" (Burnier 2009 cited in Sandberg and Elliott 2019, 2). Research on intersectional dynamics in organizations suggests giving attention to issues of power and intersectionality (Atewologun, Sealy, and Vinnicombe 2015). Hall (2015) reminds us that anti-violence work will be limited until it includes "an analysis of imperialism, racism, homophobia, and capitalism," thus expanding, not contracting, feminist understandings of violence to insure the survival and care of all peoples (410). A discourse focused on care minimizes the significance given 
efficiency and neutrality and increases "values of empathy, sympathy, and responsiveness" (Sandberg and Elliott 2019,5). Moreover, a care-centered feminist economic system acknowledges the social responsibility put upon women to care and provide "basic services" to children and families (Wright 1995, 867), which is often seen as less of a contribution as it occurs outside of the market (Kuiper et al., 1995). Wright (1995) suggests a care-focused system must be flexible and inclusive, resources have to be reallocated, and power redistributed more evenly across different populations. Importantly, this should lead to the prevention of violence against women because violence is a "symptom of economic and political power disparities" (Wright 1995, 886). An example of an NPO/NGO working in this direction is the Association for Women's Rights in Development (AWID), an international feminist NGO whose stated strategies include advancing "feminist agendas through work with policy makers, funders, and activists in regional and global spaces" and the creation of several partnership initiatives (AWID 2019, 5). One initiative, Building Feminist Economies, works on "tax justice and corporate accountability," and a women's economic empowerment approach described as "interconnected and intersectional" (AWID 2019, 7).

\section{Conclusion}

The purpose of this essay was to explore the implications of \#metoo and \#aidtoo for understanding NPO/NGO theory and practice. We provided an overview of how women have been subject to sexual violence in the context of NPOs / NGOs and why this violence seems to persist, discussing in particular institutional power disparities; a misogynist culture; gender mainstreaming; a focus on the individual victim and perpetrator; and the capitalist system. We also presented an intersectional feminist approach to theory and practice - or praxis - for addressing these conditions.

An intersectional feminist approach suggests multiple activities for NPOs/NGOs, including: creating more feminist and democratic organizations; changing a misogynist culture by raising up the powerful voices of women; acknowledging and treating organizations as gendered and value-laden; locating the individual in context; and working toward a more care-centered economic system. An intersectional approach is about confronting the sources of male domination and women's oppression from multiple angles. It means using a variety of approaches that are informed by diverse voices and experiences and supported by a collective movement of individuals brought together by their oppressed status so as to build more equitable and accountable social structures and institutions. Key to this approach is emancipation that embraces collective action and inclusive practices to create space for discourse that makes achieving systemic changes possible through people working together in solidarity.

\section{Notes}

1 Nonprofit organizations (NPOs) in the U. S. are institutions designated by state governments as nonprofit corporations and often by the U.S. Internal Revenue Service as tax-exempt. The term nonprofit, then, designates a legal and regulatory status for an organization that typically does work related to the arts, education, health care, and social welfare. Nongovernmental organization (NGO) is the term typically used for nonprofit-like organizations operating in countries outside of the U.S. While we refer to the larger sector as NPO/NGO, our particular focus in this paper is on NPO/NGO humanitarian aid organizations.

2 We use the term sexual violence throughout the paper as an all-encompassing, non-legal term that can refer to sexual assault, rape, or sexual abuse, exploitation or harassment.

3 Following McLaren et al. (2010), we define praxis as: "the union of action and reflection and of theory and practice" (p. 151).

\section{References}

Alcoff, L. M. 2009. “Discourses of Sexual Violence in a Clobal Framework." Philosophical Topics 37 (2): 123-39.

Allen, A. 2016. “Feminist Perspectives on Power.” In The Stanford Encyclopedia of Philosophy, edited by Edward N. Zalta. https://plato.stanford.edu/entries/feminist-power/.

Anderson, E. 2019. “Feminist Epistemology and Philosophy of Science". In Stanford Encyclopedia of Philosophy, edited by E. N. Zalta. https://plato.stanford.edu/entries/feminism-epistemology/.

Association for Women's Rights in Development. 2019. Homepage. https://www.awid.org.

Atewologun, D., R. Sealy, and S. Vinnicombe. 2015. “Revealing Intersectional Dynamics in Organizations: Introducing Intersectional Identity Work." Gender, Work, and Organization 23 (3): 201-22.

Ather, R. A. 2013. "Sexual Harassment at Workplace and Protective Measures for Women: National and International Perspectives." IUP Law Review 3 (4): 33-43. 
Bacchi, U. 2018. “Exclusive: More than 120 Aid Workers Sacked, Lost Jobs over Sexual Misconduct in 2017, Survey." Reuters, February $21,2018$. https://www.reuters.com/article/us-britain-aid-harassment-exclusive/exclusive-more-than-120-aid-workers-sacked-lost-jobs-oversexual-misconduct-in-2017-survey-idUSKCN1G52AE.

Batliwala, S. 1994. “The Meaning of Women's Empowerment: New Concepts from Action." In Population Policies Reconsidered: Health, Empowerment and Rights, edited by G. Sen, A. Cermain, and L. C. Chen, 127-38. Cambridge, Massachusetts: Harvard Center for Population and Development Studies.

Becker, M. 1999. "Patriarchy and Inequality: Towards a Substantive Feminism." The University of Chicago Legal Forum 1: 21-88.

Berdahl, J. L., and J. L. Raver. 2011. "Sexual Harassment." In APA Handbooks in Psychology. APA Handbook of Industrial and Organizational Psychology, Vol. 3. Maintaining, Expanding, and Contracting the Organization, edited by S. Zedeck, 641-69. Washington, DC: American Psychological Association.

Bilge, S. 2010. “Recent Feminist Outlooks on Intersectionality." Diogenes 57 (1): 58-72.

Burgess, S. K. 2018. "Between the Desire for Law and the Law of Desire: \#MeToo and the Cost of Telling the Truth Today." Philosophy \& Rhetoric $51(4): 342-67$.

Burnier, D. 2003. “Other Voices/Other Rooms: Towards a Care-Centered Public Administration." Administrative Theory \& Praxis 25 (4): $529-44$.

Carastathis, A. 2014. "The Concept of Intersectionality in Feminist Theory." Philosophy Compass 9 (5): 304-14.

Carline, A., and P. Easteal. 2014. Shades of Grey—Domestic and Sexual Violence Against Women: Law Reform and Society. New York, NY: Routledge.

Carolei, D. 2019. "Charity Self-Regulation: A Commentary on the NCVO's Code of Ethics 2018." Voluntary Sector Review 10 (1): 59-67.

ChangingAid. 2018. "Progress Report." Sexual Harassment, Abuse and Exploitation in the Aid Sector. https://www.changingaid.org/surveyresults.html.

Chernesky, R. H. 1995. “Feminist Administration: Style, Structure, Purpose.” In Feminist Practice in the 21st Century, edited by N. Van Den Bergh, 70-88. Washington, DC: National Association of Social Workers Press.

Cho, S., K. Crenshaw, and L. McCall. 2013. "Toward of Field of Intersectioanlity Studies: Theory, Applications, and Praxis." Intersectionality: Theorizing Power, Empowering Theory. The University of Chicago Press Journals 38 (4): 785-810.

Collins, P. H. 2002. Black Feminist Thought: Knowledge, Consciousness, and the Politics of Empowerment. New York, NY: Routledge.

Crenshaw, K. 1989. “Demarginalizing the Intersection of Race and Sex: A Black Feminist Critique of Antidiscrimination Doctrine, Feminist Theory and Antiracist Politics." University ofChicago Legal Forum 1989 (1): 139-67.

Crenshaw, K. 1990. “Mapping the Margins: Intersectionality, Identity Politics, and Violence against Women of Color." Stanford Law Review 43: 1241.

Danyi, C. J. 2019. "Case Study of Organizational Crisis Communication: Oxfam Responds to Sexual Harassment and Abuse Scandal." In Handbook of Communication for Development and Social Change, edited by J. Servaes, 1-13. Singapore: Springer.

Deggans, J. 2018. "Cendered Inequalities in the Workplace Revisited: Masculinist Dominance, Institutionalized Sexism, and Assaultive Behavior in the \#MeToo Era." Contemporary Readings in Law and Social Justice 10 (2): 43-49.

Durazo, A. C. R. Incite! Women of Color Against Violence. 2007. “'We Were Never Meant to Survive': Fighting Violence Against Women and the Fourth World War," in The Revolution Will Not Be Funded: Beyond the Non-Profit Industrial Complex, 113-28. Cambridge, MA: South End Press.

Einspahr, J. 2010. “Structural Domination and Structural Freedom: A Feminist Perspective." Feminist Review 94 (1): 1-19.

Eveline, J., and C. Bacchi. 2006. "What are We Mainstreaming When We Mainstream Cender?" International Feminist Journal of Politics 7 (4): 496-512.

Federici, S. 2018. "Marx and Feminism." TripleC (Cognition, Communication, Co-Operation): Open Access Journal for a Clobal Sustainable Information Society 16 (2): 468-75.

Ferguson, K. F. 1984. The Feminist Case Against Bureaucracy. Philadelphia: Temple University Press.

Garrie, D. B. 2011. "Sexual Harassment: Limiting the Affirmative Defense in the Digital Workplace." Michigan Journal of International Law 19 (1): 229.

Gilbert, P. A. 2002. “Discourses of Female Violence and Societal Cender Stereotypes.” Violence Against Women 8 (11): 1271-300.

Hall, R. J. 2015. "Feminist Strategies to End Violence Against Women." In The Oxford Handbook of Transnational Feminist Movements, edited by R. Baksh, and W. Harcourt, 394-415. Oxford: Oxford University Press.

Hallock, K. 2002. “The Cender Pay and Employment Caps for Top Managers in U.S. Nonprofits." Working Paper. Cornell University, School of Industrial and Labor Relations. https://digitalcommons.ilr.cornell.edu/workingpapers/93.

Harnois, C. E. 2012. "Sociological Research on Feminism and the Women's Movement: Ideology, Identity, and Practice." Sociology Compass 6 (10): 823-32.

Harris Insights \& Analytics. 2018. "Professional Harassment Survey." Prepared for The Chronicle of Philanthropy and The Association of Fundraising Professionals. https://chronicle-assets.s3.amazonaws.com/7/items/biz/pdf/ProfessionalHarassmentSurveyResultsPDF.pdf.

Herzog, S. 2010. "Public Perceptions of Sexual Harassment in Israel: An Empirical Analysis of Fitzgerald and Her Associates' Typology of Sexual Harassment Behaviors." In Sexual Harassment around the Clobe, edited by K. C. Wong, 1-29. New York: Nova Science Publishers.

Hildwein, F. 2016. "How a Feminist Activist Group Builds Its Repertoire of Actions: A Case Study." In Women's Emancipation and Civil Society Organisations: Challenging or Maintaining the Status Quo?, edited by C. Schwabenland, C. Lange, J. Onyx, and S. Nakagawa, 113-33. Oak Park Hill, UK: Policy Press.

Hooks, B. 1984. Feminist Theory from Margin to Center. Boston, MA: South End Press.

House of Commons. 2018. "Sexual Exploitation and Abuse in the Aid Sector." HC 840. Eighth Report of Session 2017-19. London: International Development Committee. https://publications.parliament.uk/pa/cm201719/cmselect/cmintdev/840/840.pdf.

Humanitarian Women's Network. 2016. "Full Survey Results." Humanitarian Women's Network. https://interagencystandingcommittee.org/system/files/hwn_full_survey_results_may_2016.pdf.

Hunnicutt, G. 2009. "Varieties of Patriarchy and Violence Against Women: Resurrecting Patriarchy as a Theoretical Tool." Violence Against Women 15 (5): 553-73. 
Jasinski, J. L. 2001. “Theoretical Explanations for Violence Against Women.” In Sourcebook on Violence Against Women, edited by C. M. Renzetti, J. L. Edleson, and R. K. Bergen, 5-21. Thousand Oaks, CA: Sage.

Kalra, G., and D. Bhugra. 2013. "Sexual Violence Against Women: Understanding Cross-cultural Intersections." Indian Journal of Psychiatry 55 (3): 244-49.

Kivel, P. 2007. "Social Service or Social Change?" In The Revolution Will Not Be Funded: Beyond the Non-Profit Industrial Complex, edited by Incite! Women of Color Against Violence, 129-49. Cambridge, MA: South End Press.

Knight, L. W. 1991. “Jane Addams and Hull House: Historical Lessons on Nonprofit Leadership.” Nonprofit Management \& Leadership 2 (2): 12541.

Kuiper, E., J. Sap, S. Feiner, and Z. Tzannatos, eds. 1995. Out of the Margin: Feminist Perspectives on Economics. Psychology Press.

Kunwar, L. B., B. B. Kunwar, P. Thapa, I. Sharma, S. S. Dhami, and L. J. Rokaya. 2015. “Sexual Harassment in Female at Working Place in Dhangadhi Municipality Kailali District of Nepal." Indian Journal of Public Health Research \& Development 6 (4): 18-21.

Lakeman, L. 2000. “Why Law and Order Cannot End Violence of Women." Canadian Women's Studies 20 (3): 24-33. https://cws.journals.yorku.ca/index.php/cws/article/view/12659.

Lanfranchi, J., and M. Narcy. 2015. “Female Overrepresentation in Public and Nonprofit Sector Jobs: Evidence from a French National Survey." Nonprofit and Voluntary Sector Quarterly 44 (1): 47-74. https://doi.org/10.1177/0899764013502579.

Leong, N. 2019. "Them Too." Washington University Law Review 96. https://ssrn.com/abstract=3118040.

Lerner, G. 1986. The Creation of Patriarchy. New York, NY: Oxford University Press.

Mackinnon, C. A. 1989. Toward a Feminist Theory of the State. Cambridge: Harvard University Press.

MacKinnon, C. A. 2018. "\#MeToo Has Done What the Law Could Not." The New York Times, February 4, 2018. https://www.nytimes.com/2018/02/04/opinion/metoo-law-legal-system.html.

Mazurana, D., and P. Mazurana. 2017. "STOP the Sexual Assault Against Humanitarian and Development Aid Workers." Somerville, MA: Feinstein International Center, Tufts University. http://fic.tufts.edu/publication-item/stop-sexual-assault-against-aid-workers/.

McAfee, N. 2018. “Feminist Philosophy." In The Stanford Encyclopedia of Philosophy, edited by Edward N. Zalta. https://plato.stanford.edu/cgibin/encyclopedia/archinfo.cgi?entry=feminist-philosophy.

McLaren, P., J. Ryoo, J. Crawford, and D. Moreno. 2010. “Critical Praxis.” In Encyclopedia ofCurriculum Studies, edited by C. Kridel, 151. Thousand Oaks, CA: Sage.

Me Too Movement. 2018. “History \& Vision.” Me Too Movement. https://metoomvmt.org/about/.

Merry, S. E. 2011. Cender Violence: A Cultural Perspective, Vol. 3. Oxford: John Wiley \& Sons.

Miller, A. M. 2004. "Sexuality, Violence Against Women, and Human Rights: Women Make Demands and Ladies Cet Protection." Health and Human Rights 7 (2): 16-47.

Namy, S, C. Carlson, K. O’ Hara, J. Nakuti, P. Bukuluki, J. Lwanyaaga, S. Namakula, et al. 2017. “Towards a Feminist Understanding of Intersecting Violence Against Women and Children in the Family." Social Science \& Medicine 184: 40-48.

Nickel, P. M., and A. M. Eikenberry. 2006. "Beyond Public vs. Private: the Transformative Potential of Democratic Feminist Management." Administrative Theory \& Praxis 28 (3): 359-80.

Nozawa, J. T. 2010. "The Class Ceiling of Nonprofits: A Review of Gender Inequality in US Nonprofit Organization Executives." Policy InDepth. Salt Lake City, UT: Center for Public Policy \& Administration, The University of Utah.

O'Neil, D. A., and M. M. Hopkins. 2015. “The Impact of Cendered Organizational Systems on Women's Career Advancement." Frontiers in Psychology 6: 905.

Oxfam. 2018. "Safeguarding." Oxfam. https://www.oxfam.org.uk/safeguarding-at-oxfam.

Ozkazanc-Pan, B. 2019. “On Agency and Empowerment in a \#MeToo World." Cender Work Organ 26 (8): 1-9. https://onlinelibrary.wiley.com/doi/abs/10.1111/gwao.12311.

Phillips, R. 2016. “A Clobal Analysis of the Empowerment Paradigm and the Influence of Feminism in Women's NCOs." In Women's Emancipation and Civil Society Organisations: Challenging or Maintaining the Status Quo?, edited by C. Schwabenland, C. Lange, J. Onyx, and S. Nakagawa, 21-45. Oak Park Hill, UK: Policy Press.

Renock, R. 2017. “Sexism \& Nonprofits, Dismissing a Sector Run by Women.” Medium, July 19, 2017. https://medium.com/the-nonprofitrevolution/sexism-nonprofits-dismissing-a-sector-run-by-women-dc7d71790307.

Sampson, S. D., and L. L. Moore. 2008. “Is There a Class Ceiling for Women in Development?” Nonprofit Management and Leadership 18 (3): 321-39. https://doi.org/10.1002/nml.188.

Sandberg, B., and E. Elliott. 2019. "Toward a Care-Centered Approach for Nonprofit Management in a Neoliberal Era." Administrative Theory 8 Praxis. https://doi.org/10.1080/10841806.2019.1621661.

Sandoval, T. 2018. "Sexual Harassment Is Widespread Problem for Fundraisers, Survey Shows." The Chronicle of Philanthropy, April 5, 2018. https://www.philanthropy.com/interactives/fundraiser-poll.

Schwabenland, C., C. Lange, J. Onyx, and S. Nakagawa. 2016. "Introducing the Anthology." In Women's Emancipation and Civil Society Organisations: Challenging or Maintaining the Status Quo?, edited by C. Schwabenland, C. Lange, J. Onyx, and S. Nakagawa, 1-20. Oak Park Hill, UK: Policy Press.

Shapiro, J. 2018. “The Sexual Assault Epidemic No One Talks About.” NPR.Org, January 8, 2018. https://www.npr.org/2018/01/08/570224090/the-sexual-assault-epidemic-no-one-talks-about.

Sokoloff, N. J. 2004. “Domestic Violence at the Crossroads: Violence Against Poor Women and Women of Color." Women's Studies Quarterly $32(3 / 4): 139-47$.

St. Germain, T., and S. Dewey. 2012. “Introduction.” In Conflict-Related Sexual Violence: International Law, Local Responses, edited by T. St Cermain, and S. Dewey, 1-14. Sterling, VA: Kumarian Press.

Stivers, C. 1993. Cender Images in Public Administration, Legitimacy and the Administrative State. Newbury Park, CA: Sage.

Stivers, C. 2000. Bureau Men, Settlement Women: Constructing Public Administration in the Progressive Era. Lawrence, KS: The University Press of Kansas.

Summerson Carr, E. 2003. “Rethinking Empowerment Theory Using a Feminist Lens: The Importance of Process.” Affilia 18 (1): 8-20. 
Teasdale, S., S. McKay, J. Phillimore, and N. Teasdale. 2011. “Exploring Cender and Social Entrepreneurship: Women's Leadership, Employment and Participation in the Third Sector and Social Enterprises." Voluntary Sector Review 2 (1): 57-76.

Tong, R. 2013. Feminist Thought: A More Comprehensive Introduction, 4th ed. Charlotte, NC: Westview Press.

Tremblay, R. C. 1999. "Inclusive Administration and Development: Feminist Critiques of Bureaucracy." In Bureaucracy and the Alternatives in World Perspective, edited by K. M. Henderson, and O. P. Dwivedi, 69-94. New York, N.Y.: St Martin's Press, Inc.

UN Women. 2014. Cender Mainstreaming in Development Programming. New York: UN Women.

Wakefield, S. 2017. Transformative and Feminist Leadership for Women's Rights. Boston: Oxfam.

Wallace, T., L Bornstein, and ]. Chapman. 2007. The Aid Chain: Coercion and Commitment in Development NCOs. Rugby, UK: Practical Action Pub. Weldon, S. L. 2019. "Power, Exclusion and Empowerment: Feminist Innovation in Political Science.” Women's Studies International Forum 72 (January-February): 127-36.

Williams, C. L., C. Muller, and K. Kilanski. 2012. “Cendered Organizations in the New Economy.” Cender and Society 26 (4): 549-73.

Winter, B. 2012. "International versus Transnational? The Politics of Prefixes in Feminist International Relations." In Conflict-Related Sexual Violence: International Law, Local Responses, edited by T. St. Cermain, and S. Dewey, 33-52. Sterling, VA: Kumarian Press.

Wright, S. 1995. "Women and the Clobal Economic Order: A Feminist Perspective." American University International Law Review 10 (2): 861-67.

Yodanis, C. L. 2004. “Cender Inequality, Violence Against Women, and Fear: A Cross-National Test of the Feminist Theory of Violence Against Women." Journal of Interpersonal Violence 19 (6): 655-75. 